\title{
Selected Macro - Economic Variables and its Impact on Chinese and Indian Exports
}

\author{
*Rohit Singh Tomar, ${ }^{* *}$ Dr. Deepika Singh Tomar \\ Lecturer, Amity University, Gwalior, Madhya Pradesh, 474020, India \\ Lecturer, Amity University, Gwalior, Madhya Pradesh, 474020, India
}

\begin{abstract}
There is a wide cleft between the exports from India to the world and exports from China to the world. The share of Chinese and Indian exports is $11.13 \%$ and $1.60 \%$ (WTO, 2012) respectively of the overall worlds' export. This prompts us to find out the impact of selected Indian and Chinese macro economical variables on the exports from India and China respectively.

This research is divided at three levels - At first level macro economic variables which put an impact on exports from any country are selected. The selected variables are Gross Domestic Product (GDP), FDI inflows, Exchange Rate, Per Capita Real Income and Inflation. At second level an econometric model has been designed to predict the impact of selected macro economic variables of Indian economy on the export of China and the impact of selected macroeconomic variable of Chinese economy on the export of India. The current research would enable us to predict the export of both China and India and would help in formulating export strategies of the country. At third level polices are suggested on the basis of the model to improve the exports from India.

Principal component regression analysis is used to prepare economic model from the selected independent macro economic variables. Numbers of selected variables are not exhaustive leaving an opportunity for others to further explore them.
\end{abstract}

Key Words: Export Policies, Exchange Rate, G.D.P, FDI Inflows \& Inflation.

\section{Introduction}

India's exports have grown rapidly in the past decade. Simultaneously exports from China have grown in leaps and bound. These two developing nations are rapidly growing as an economic power at world's arena. But China's share is $11.13 \%$ of the world's total export and India's share is $1.6 \%$ (WTO, 2012) of the world's total export. Total exports from China are almost seven times higher than that of total export from India (calculated from Table-1 in appendix). This shows a significant difference in the export performance of China and India. After primary review it has been found that other economic parameters like G.D.P growth rate, G.D.P per capita, Foreign Direct Investment (F.D.I) net inflows as percentage of G.D.P, and Inflation (at consumer prices) of India and China have shown considerable differences in last one decade. However, all above economic parameters have shown an incremental trend in both India and China but relatively performance of India is weak as compared to China on these economic parameters. We are interested to find out that if there is any impact of these variables on the export performances of both China and India. Therefore at first level of our research we need to justify the selection of these variables. For this intensive literature review is done. At second level of the research an econometric model has been designed to predict the impact of selected macro economic variables of Indian economy on the export of China and the impact of selected macroeconomic variable of Chinese economy on the export of India. At third level policies are suggested on the basis of model to improve the exports from India.

\section{Review of Literature}

Gross Domestic Product (G.D.P) is considered to be the sum of all the final services and products produced inside the national economy in the given time (Aslanov E., et.al. 2010). GDP real growth means the increase of wealth and social welfare in the country (McConnell and Brue, 2008). China and India have shown a continuous increase in the G.D.P growth rate from 2000 to 2007 slight decline could be seen in G.D.P growth rate from 2007 to 2012 (Table-2). Except for year 2010 there is significant difference in the G.D.P growth rate of two countries from 2000 to 2012 . G.D.P growth rate is related with exports, more references could be found in Table-3.

Foreign Direct Investment (F.D.I) net inflows as percentage of G.D.P is the net investment of foreign assets into domestic country in the form of infrastructure, business organization, trade and equipments. F.D.I net inflows have been more than double in China than in India for the year 2011 (see Table-4 in appendix). From years it has been significantly high in China as compared to India. Exports and economic growth rate have shown a positive relationship with F.D.I inflows (see Table-3 for references). 
Exchange rate is the price of one country's money in terms of units of another country's money (www.research.stlouisfed.org). In the last decade fluctuations in the official exchange rate of China have been less as compared to fluctuation in the official exchange rate of India. Standard deviation in the exchange rate of China is 0.79 while the same has found to be 2.93 for India (See Table -5 in appendix).

G.D.P per capita income of both countries India and China have shown a significant level of increment. But G.D.P per capita income of India is much less (mean=914.64 US\$, from 2000 to 2012) than the G.D.P per capita of China (mean=2737.12 US\$, from 2000 to 2012) (see Table -6 in appendix).

McConnell and Brue (2008) define inflation as "rising level of prices". India's rate of inflation is higher than China's rate of inflation, with average growth rate of 6.6\% and 2.3\% respectively from 2000 to 2012.

All above economic indicators are selected on the basis of the references done by other economist mention in Table-3 as they seem to put an impact on the exports (dependent variable).

Table-3 Macro-economic variables and its impact on export -

\begin{tabular}{|c|c|c|}
\hline $\begin{array}{l}\text { Macro- } \\
\text { Economic } \\
\text { Variable }\end{array}$ & Impact on Export & Reference \\
\hline GDP & $\begin{array}{l}\text { The exports and imports were highly significant for three South Caucasus countries - } \\
\text { Azerbaijan, } \\
\text { Georgia and Armenia. } \\
\text { The analysis of the relation between GDP and exports shows that GDP growth is related } \\
\text { with export. }\end{array}$ & Aslanov E. et.al \\
\hline \multirow{5}{*}{$\begin{array}{l}\text { FDI } \\
\text { inflows }\end{array}$} & There is a relationship between Exports and FDI inflows in Pakastan. & Shahzad A. \& Kaid Al-Swidi A. \\
\hline & Volume of exports of a country tends to attract the FDI inflows. & $\begin{array}{l}\text { Navaretti, G. B. et.al. } \\
\text { Markusen, J. R., \& Maskus, K. E. }\end{array}$ \\
\hline & $\begin{array}{l}\text { Import, export and Economic growth, posited to have a positive causal relationship with } \\
\text { FDI inflows. }\end{array}$ & Jayachandran, G., \& Seilan, A. \\
\hline & There is a significant positive impact of foreign trade on FDI inflows & $\begin{array}{l}\text { Liu, X., Burridge, P., \& Sinclair, } \\
\text { P. J. N. }\end{array}$ \\
\hline & Positive relationship between imports and FDI inflows & Aizenman, J., \& Noy, I. \\
\hline $\begin{array}{l}\text { Exchange } \\
\text { - rate }\end{array}$ & $\begin{array}{l}\text { Empirical analysis reveals that indeed over the sample period a currency appreciation had } \\
\text { a strong and significant negative impact on Indian firms' export shares. } \\
\text { The real trade-weighted exchange rate and trade partner income are shown to be key } \\
\text { determinants of U.S. agricultural exports. } \\
\text { China's undervalued yuan: China held its yuan steady for a decade from } 1994 \text { to 2004, } \\
\text { enabling its export juggernaut to gather tremendous momentum from an undervalued } \\
\text { currency. }\end{array}$ & Wong Cheung Y. \& Sengupta R. \\
\hline $\begin{array}{l}\text { Per capita } \\
\text { real } \\
\text { income }\end{array}$ & $\begin{array}{l}\text { There is positive correlation between export openness and income levels. Import openness } \\
\text { correlates negatively with countries' incomes. }\end{array}$ & Zhang S. \& Odrich Z. \\
\hline Inflation & In Azerbaijan and Georgia inflation has an impact on export. & $\begin{array}{l}\text { Aslanov E., Gasimov T. \& } \\
\text { Isayeva A. }\end{array}$ \\
\hline
\end{tabular}

\section{The Conceptual Model}

At second level an econometric model has been designed to predict the impact of selected macro economic variables of Indian economy on the export of China and the impact of selected macroeconomic variable of Chinese economy on the export of India. As mentioned earlier, dependent variable in this study is exports and the independent variables are G.D.P, F.D.I net inflows, exchange rate, G.D.P per capita, and inflation. In our research we are trying to analyze the relationship between dependent and independent variables. Linear model for the two countries are formulated and the conceptual model illustrated in Figure 1 are based on the literature review: 
Figure 1:

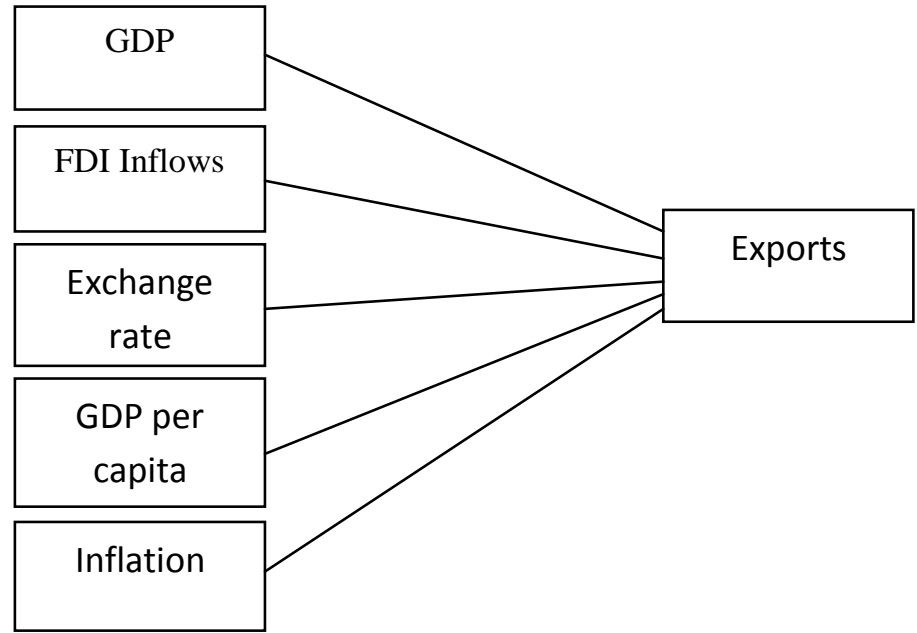

\section{Data analysis -}

Secondary data from 2000 to 2012 has been collected from the official website of World Trade Organisation (WTO). Principal component regression analysis is used to prepare economic model from the selected independent macro economic variables. SPSS 19.0 is used for data analysis and results are tabulated.

\section{Hypothesis testing -}

I. Exports from China depend on the selected macro-economic variables of China.

(a) GDP growth rate of China is related to the exports from China.

(b) FDI inflows to China are related to the exports from China.

(c) Exchange rates of domestic currency of China are related to the exports from China.

(d) GDP per capita of China are related to the exports from China.

(e) Growth rate of inflation is related to exports from China.

Exports $_{\text {China }}=\beta_{0}+\beta_{1}$ G.D.P China $+\beta_{2}$ FDI $_{\text {China }}+\beta_{3}$ Exchange Rate $_{\text {China }}+\beta_{4}$ G.D.P per capita ${ }_{\text {China }}+\beta_{5}$ Inflation China

$\mathrm{R}$ square tells us how much variance in the dependent variable that is explained by the model (Pallant 2007). Our model explains $96.6 \%$ of the variance in the exports which is quite respectable result and considered satisfactory. Also $\mathrm{F}$ value is significant suggesting that exports from China depend on the selected macroeconomic variables from China. GDP, GDP per capita and inflation in China shows significant and positive relationship with exports from China with p-value $0.009,0.001$ and .008 respectively. This fits with the findings of Aslanov et.al. and Zhang S. (Table - 3). While negative official exchange rate is not significant with exports from China also positive FDI inflows is not significant with exports from China (Table -8$)$.

Table - 8

\begin{tabular}{c|ccc} 
Model & SS & dE & MS \\
\hline Regression & $4.595 \mathrm{E} 12$ & 5 & $9.190 \mathrm{E} 11$ \\
Residual & $1.623 \mathrm{E} 10$ & 7 & $2.318 \mathrm{E} 9$ \\
\hline Total & $4.611 \mathrm{E} 12$ & 12 &
\end{tabular}

$$
\begin{array}{ll}
\text { Number of obs } & =12 \\
\text { F }(5,7) & =396.413 \\
\text { R }- \text { Squared } & =0.996 \\
\text { Adj. R-Squared } & =0.994 \\
\text { Std. Error } & =14408
\end{array}
$$

\begin{tabular}{|c|c|c|c|c|c|}
\hline \multirow{2}{*}{ Model } & \multicolumn{2}{|c|}{ Unstandardized Coefficients } & \multicolumn{1}{c|}{$\begin{array}{c}\text { Standardized } \\
\text { Coefficients }\end{array}$} & & \\
\cline { 2 - 5 } & $\mathrm{B}$ & Std. Error & Beta & $\mathrm{t}$ & Sig. \\
\hline (Constant) & 950316.959 & 776374.237 & & 1.224 & .261 \\
GDPCHINA & 38907.675 & 10961.139 & .122 & 3.550 & .009 \\
OERChina & -177943.922 & 91717.366 & -.226 & -1.940 & .094 \\
GDPPerCapita & 248.881 & 41.936 & .709 & 5.935 & .001 \\
FDIChina & 69083.082 & 37615.424 & .070 & 1.837 & .109
\end{tabular}




\begin{tabular}{rl|l|l|l|l|l|l|}
\hline & InflationChina & 29092.926 & 8024.526 & .104 & 3.626 & .008 \\
\hline a. $\quad$ Dependent Variable: ExportChina
\end{tabular}

II Exports from China depends on the selected macro-economic variables of India.

(a) GDP growth rate of India is related to the exports from China.

(b) FDI inflows to India are related to the exports from China.

(c) Exchange rates of domestic currency of India are related to the exports from China.

(d) GDP per capita of India are related to the exports from China.

(e) Growth rate of inflation is related to exports from China.

Exports $_{\text {China }}=\beta_{0}+\beta_{1}$ G.D.P India $+\beta_{2}$ FDI $_{\text {India }}+\beta_{3}$ Exchange Rate $_{\text {India }}+\beta_{4}$ G.D.P per capita India $+\beta_{5}$ Inflation India

Model explains 99\% variation in the exports from China due to selected macro-economic variables of the Indian economy. Also $\mathrm{F}$ value is significant suggesting that exports from China depend on the selected macroeconomic variables of India. GDP per capita of India, FDI inflows in India and inflation in India have shown significant relationship with exports from China, with $p$ value $0.00,0.022$ and 0.19 respectively. In fact growth rate of inflation in India is inversely related to exports from China. While negative relationship of GDP of India and Chinese exports are not significant also official exchange rate of currency is not significantly related to the exports from China.

Table - 9

\begin{tabular}{|c|c|c|c|c|c|}
\hline Model & SS & $\mathrm{dF}$ & MS & \multirow{4}{*}{$\begin{array}{l}\text { Number of obs } \\
\text { F ( } 5,7 \text { ) } \\
\text { R - Squared } \\
\text { Adj. R - Squared } \\
\text { Std. Error }\end{array}$} & \multirow{4}{*}{$\begin{aligned}= & 12 \\
= & 145.667 \\
= & 0.99 \\
& =0.984 \\
= & 79188\end{aligned}$} \\
\hline Regression & $4.567 \mathrm{E} 12$ & 5 & $9.134 \mathrm{E} 11$ & & \\
\hline Residual & $4.390 \mathrm{E} 10$ & 7 & $6.271 \mathrm{E} 9$ & & \\
\hline Total & $4.611 \mathrm{E} 12$ & 12 & & & \\
\hline
\end{tabular}

\begin{tabular}{|c|c|c|c|c|c|}
\hline \multirow[b]{2}{*}{ Model } & \multicolumn{2}{|c|}{ Unstandardized Coefficients } & \multirow{2}{*}{$\begin{array}{c}\text { Standardized } \\
\text { Coefficients }\end{array}$} & \multirow[b]{2}{*}{$\mathrm{t}$} & \multirow[b]{2}{*}{ Sig. } \\
\hline & B & Std. Error & & & \\
\hline (Constant) & -860024.078 & 596212.934 & & -1.442 & .192 \\
\hline GDPIndia & -8077.516 & 12501.544 & -.034 & -.646 & .539 \\
\hline OfficialExchange & 10388.951 & 11896.957 & .049 & .873 & .411 \\
\hline GDPPerCapita & 1799.447 & 126.049 & 1.152 & 14.276 & .000 \\
\hline FDIIndia & 131353.970 & 44598.260 & .178 & 2.945 & .022 \\
\hline IndiaInflation & -63726.599 & 21041.479 & -.304 & -3.029 & .019 \\
\hline
\end{tabular}

III Exports from India depends on the selected macro-economic variables of India.

(a) GDP growth rate of India is related to the exports from India.

(b) FDI inflows to India are related to the exports from India.

(c) Exchange rates of domestic currency of India are related to the exports from India.

(d) GDP per capita of India are related to the exports from India.

(e) Growth rate of inflation is related to exports from India.

Exports $_{\text {India }}=\beta_{0}+\beta_{1}$ G.D.P India $+\beta_{2}$ FDI $_{\text {India }}+\beta_{3}$ Exchange Rate $_{\text {India }}+\beta_{4}$ G.D.P per capita India $+\beta_{5}$ Inflation $_{\text {India }}$ Model explains $98.7 \%$ variations in the exports from India due to selected macro-economic variables of Indian economy. Exports from India significantly depend on the selected macro-economic variables of India. GDP growth rate of India and GDP per capita of India are significantly related to the exports from India. But beta value for GDP is negative showing a negative relationship between GDP growth rate of India and exports from India. This shows that major contributing sectors in GDP growth rate are not contributing in exports perhaps domestic consumptions of such goods and services are high or produced goods and services are not of export quality. Therefore further study is required to find out why sectors contributing in GDP growth 
rate are not contributing in exports. While all other variables like FDI inflows, official exchange rate and inflation rate of India do not have significant relationship with exports from India.

Table - 10

\begin{tabular}{c|lcc} 
Model & SS & $\mathrm{dF}$ & \multicolumn{2}{c}{$\mathrm{MS}$} \\
\hline Regression & $1.080 \mathrm{E} 11$ & 5 & $2.161 \mathrm{E} 10$ \\
Residual & $1.453 \mathrm{E} 11$ & 7 & $2.076 \mathrm{E} 8$ \\
\hline Total & $1.95 \mathrm{E} 11$ & 12 &
\end{tabular}

$$
\begin{array}{ll}
\text { Number of obs } & =12 \\
\mathrm{~F}(5,7) & =104.079 \\
\mathrm{R}-\text { Squared } & =.987 \\
\text { Adj. } \mathrm{R}-\text { Squared } & =.977 \\
\text { Std. Error } & =14408
\end{array}
$$

\begin{tabular}{|c|c|c|c|c|c|}
\hline \multirow[b]{2}{*}{ Model } & \multicolumn{2}{|c|}{ Unstandardized Coefficients } & \multirow{2}{*}{$\frac{\begin{array}{c}\text { Standardized } \\
\text { Coefficients }\end{array}}{\text { Beta }}$} & \multirow[b]{2}{*}{$\mathrm{t}$} & \multirow[b]{2}{*}{ Sig. } \\
\hline & $\mathrm{B}$ & Std. Error & & & \\
\hline (Constant) & 35695.902 & 108480.261 & & .329 & .752 \\
\hline GDPIndia & -5410.101 & 2274.642 & -.148 & -2.378 & .049 \\
\hline OERIndia & -1658.533 & 2164.638 & -.051 & -.766 & .469 \\
\hline GDPPerCapita & 252.244 & 22.934 & 1.048 & 10.998 & .000 \\
\hline FDIIndia & -6955.627 & 8114.602 & -.061 & -.857 & .420 \\
\hline InflationIndia & 264.903 & 3828.473 & .008 & .069 & .947 \\
\hline
\end{tabular}

IV Exports from India depends on the selected macro-economic variables of China.

(a) GDP growth rate of China is positively related to the exports from India.

(b) FDI inflows to China are positively related to the exports from India.

(c) Exchange rates of domestic currency of China are related to the exports from India.

(d) GDP per capita of China are positively related to the exports from India.

(e) Growth rate of inflation is related to exports from India.

Exports $_{\text {India }}=\beta_{0}+\beta_{1}$ G.D.P China $+\beta_{2}$ FDI China $+\beta_{3}$ Exchange Rate $_{\text {China }}+\beta_{4}$ G.D.P per capita ${ }_{\text {China }}+\beta_{5}$ Inflation China

The model suggests $98.7 \%$ variations in the exports from India due to variations in the macro-economic variables of Chinese economy. GDP per capita income of China has shown significant relationship with exports from India. While all other selected Chinese macro-economic variables have not shown significant relationship with the exports from India.

Table - 11

\begin{tabular}{c|ccc} 
Model & SS & $\mathrm{dF}$ & \multicolumn{2}{c}{ MS } \\
\hline Regression & $1.080 \mathrm{E} 11$ & 5 & $2.161 \mathrm{E} 10$ \\
Residual & $1.442 \mathrm{E} 9$ & 7 & $2.060 \mathrm{E} 8$ \\
\hline Total & $1.095 \mathrm{E} 11$ & 12 &
\end{tabular}

$$
\begin{array}{ll}
\text { Number of obs } & =12 \\
\mathrm{~F}(5,7) & =104.876 \\
\mathrm{R}-\text { Squared } & =0.987 \\
\text { Adj. } \mathrm{R}-\text { Squared } & =0.977 \\
\text { Std. Error } & =14354
\end{array}
$$

\begin{tabular}{|ll|r|r|r|r|r|}
\hline & & \multicolumn{2}{|c|}{ Unstandardized Coefficients } & \multicolumn{2}{c|}{$\begin{array}{c}\text { Standardized } \\
\text { Coefficients }\end{array}$} & \\
\cline { 3 - 6 } Model & & \multicolumn{1}{c|}{$\mathrm{B}$} & \multicolumn{1}{c|}{ Std. Error } & Beta & \multicolumn{1}{c|}{ Sig. } \\
\hline 1 & (Constant) & 178419.224 & 231455.347 & & .771 & .466 \\
& GDPCHINA & -21.303 & 3267.772 & .000 & .995 \\
& OERChina & -27688.868 & 27343.095 & -.228 & -1.013 & .345 \\
& GDPPerCapita & 37.235 & 12.502 & .688 & 2.978 & .021 \\
& FDIChina & 17135.673 & 11214.039 & .113 & 1.528 & .170 \\
& InflationChina & 4300.747 & 2392.299 & .100 & 1.798 & .115 \\
\hline
\end{tabular}




\section{Suggestions for Export Policy}

Among five selected macroeconomic variables GDP per capita have come out to be the most significant variable, which has positive relationship with the exports. Therefore both countries must focus on increasing GDP per capita to give a positive thrust to the export sector. There is an increase in the export of India if the GDP per capita of the both the country increases. Same is applicable on the China, if GDP per capita of India and China increases than Chinese exports also increases. FDI inflows in India have significantly increased Chinese exports, we need to explore the reasons behind this phenomenon perhaps FDI inflows in India are enhancing export led industrial growth of China. Also, FDI inflows in China have shown positive but insignificant growth in the Indian exports. Moreover FDI inflows in India have shown negative and insignificant relationship with exports from India that means, FDI inflows in India have not contributed in the development of the export led industries. Therefore governments try to attract such FDI inflows in India which contributes in the development of exports from India. As per Liu,X. et.al., there is a positive relationship between imports and FDI inflows, in India imports are higher than exports therefore it could be the reasons of FDI inflows in India. Inflation growth rate in India have significant and negative relationship with exports from China. Inflation growth in India has not shown significant relationship with exports from India. Official exchange rate of India has not shown significant relationship with either India or China therefore results are inconsistent with the earlier finding of the Wong Cheung \& Sengupta (Table -III).

Exhaustive study is required to find out more variables which influence exports from these countries.

\section{References}

[1]. Aizenman, J., \& Noy, I., “ FDI and trade-Two-way linkages?”, The Quarterly Review of Economics and Finance,Vol. 46, No. 3, pp. 317-337 (2005). Retrieved from Website: http://dx.doi.org/10.1016/j.qref.2006.02.004.

[2]. Aslanov E., Gasimov T. \& Isayeva A., "Analysis of Economic Factors Affecting Export and Import in the Countries of the South Caucasus", Project Prize Competition and Symposium on International Trade and Regional Integration in the South Caucasus, International School of Economics, Tbilisi State University (12.04.2010), Retrieved from Website: www.iset.gelfiles/submission_aslanov_isayeva_gasimova.pdf..

[3]. Campbell R. McConnell and Stanley L. Brue. 2008 Economics. 17th edition. McGraw-Hill.

[4]. Jayachandran, G., \& Seilan, A., " A causal relationship between Trade, Foreign Direct Investment and Economic Growth for India", International Research Journal of Finance and Economics, Vol. 42, pp. 74-88(2010).

[5]. Liu, X., Burridge, P., \& Sinclair, P. J. N. , "Relationships between economic growth, foreign direct Investment and trade: evidence from China", Applied Economics, Vol.34, No. 11, pp. 1433-1440 (2002). Retrieved from Website: http://dx.doi.org/10.1080/00036840110100835.

[6]. Navaretti, G. B., Venables, A., \& Barry, F., "Multinational firms in the world economy", Princeton University Press, Edition 2004. Markusen, J. R., \& Maskus, K. E., " Discriminating among Alternative Theories of the Multinational Enterprise", Review of International Economics, 10, 694-707, Retrieved from Website: http://dx.doi.org/10.1111/1467-9396.00359.

[7]. Pallant Julie. 2007. “A Step by Step Guide to Data Analysis using SPSS for Windows third edition”. Open University Press.

[8]. Shahzad A. \& Kaid Al-Swidi A., " Effect of Macroeconomic Variables on the FDI inflows: The Moderating Role of Political Stability: An Evidence from Pakistan”, Asian Social Science, Vol. 9, No. 9, pp. 270-279 (2013).

[9]. Shane, M., Roe, T., \& Somwaru, A., "Exchange Rate, Foreign Income, and U.S. Agricultural Exports", Agricultural and Resource Economics Review, 37/2, pp. 160-175, (October 2008). Retrieved on, 29 January 2014.

[10]. Wong Cheung Y. \& Sengupta R., "Impact of Exchange Rate Movements on Exports: An Analysis of Indian Non - Financial Sector Firms", Retrieved from Website: macrofinance.nipfp.org.in/../JIMFPR_Cheung-Sengupta_201212Final.pdf.

[11]. Zhang S. \& Odrich Z., "The Link between Trade and Income: Export Effect, Import Effect, or Both?", faculty.maxwell.syr.edu/jondrich/PapersOnLine/shuo.jan.dave-10.pdf.

[12]. http://research.stlouisfed.org/pageone-economics/uploads/newsletter/2010/201004.pdf

[13]. http://www.investopedia.com/articles/forex/080613/effects-currency-fluctuations-economy.asp

[14]. http://www. stat.wto.org/statisticalprogram/WSDB Data. Aspx? Language $=\mathrm{E}$ 
Selected Macro - Economic Variables and its Impact on Chinese and Indian Exports

\begin{tabular}{|c|c|c|}
\hline \multicolumn{3}{|c|}{$\begin{array}{l}\text { Appendix } \\
\text { Table-1 Exports from India and China } \\
\text { at current prices in US \$ Million }\end{array}$} \\
\hline Years & China & India \\
\hline 2000 & 249203 & 42379 \\
\hline 2001 & 266098 & 43361 \\
\hline 2002 & 325596 & 49250 \\
\hline 2003 & 438228 & 58963 \\
\hline 2004 & 593326 & 76649 \\
\hline 2005 & 761953 & 99616 \\
\hline 2006 & 968978 & 121808 \\
\hline 2007 & 1220456 & 150159 \\
\hline 2008 & 1430693 & 194828 \\
\hline 2009 & 1201612 & 164909 \\
\hline 2010 & 1577754 & 266350 \\
\hline 2011 & 1898381 & 302905 \\
\hline 2012 & 2048714 & 294158 \\
\hline Mean & 998537.8 & 143487.3 \\
\hline $\mathrm{SD}$ & 619888.1 & 95518.5 \\
\hline
\end{tabular}

\begin{tabular}{|r|r|r|}
\hline \multicolumn{3}{|c|}{ Table - 4 Foreign direct investment, } \\
net inflows (\% of GDP) \\
\hline Year & \multicolumn{1}{|c|}{ China } & \multicolumn{1}{l|}{ India } \\
\hline 2000 & 3.204014 & 0.755062 \\
\hline 2001 & 3.33943 & 1.111329 \\
\hline 2002 & 3.391597 & 1.076139 \\
\hline 2003 & 3.0139 & 0.699958 \\
\hline 2004 & 3.215294 & 0.799808 \\
\hline 2005 & 4.612902 & 0.871405 \\
\hline 2006 & 4.573693 & 2.11029 \\
\hline 2007 & 4.471861 & 2.03663 \\
\hline 2008 & 3.793481 & 3.545985 \\
\hline 2009 & 2.625733 & 2.605982 \\
\hline 2010 & 4.096004 & 1.548994 \\
\hline 2011 & 3.829036 & 1.718775 \\
\hline Average & 3.680579 & 1.573363 \\
\hline SD & 0.653733 & 0.877314 \\
\hline
\end{tabular}

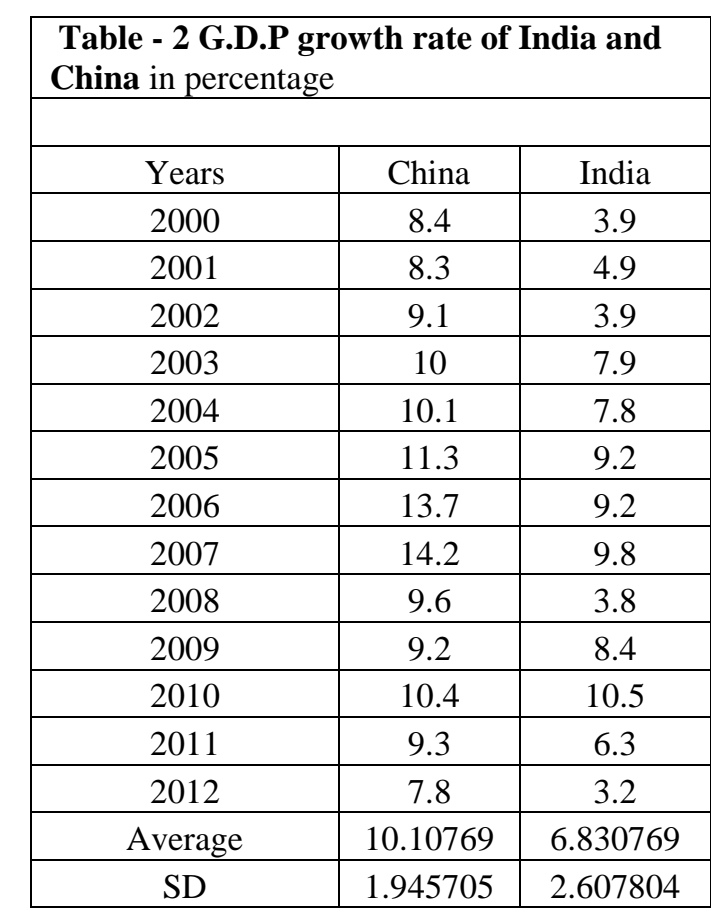

\begin{tabular}{|c|c|c|}
\hline rate & \multicolumn{2}{|c|}{$\begin{array}{l}\text { Table - } 5 \text { Official exchange } \\
\text { (LCU per US\$, period average) }\end{array}$} \\
\hline Year & China & India \\
\hline 2000 & 8.278504 & 44.94161 \\
\hline 2001 & 8.277068 & 47.18641 \\
\hline 2002 & 8.276958 & 48.61032 \\
\hline 2003 & 8.277037 & 46.58328 \\
\hline 2004 & 8.276801 & 45.31647 \\
\hline 2005 & 8.194317 & 44.09998 \\
\hline 2006 & 7.973438 & 45.30701 \\
\hline 2007 & 7.607533 & 41.34853 \\
\hline 2008 & 6.948655 & 43.50518 \\
\hline 2009 & 6.831416 & 48.40527 \\
\hline 2010 & 6.770269 & 45.72581 \\
\hline 2011 & 6.461461 & 46.67047 \\
\hline 2012 & 6.312333 & 53.43723 \\
\hline Average & 7.57583 & 46.24135 \\
\hline SD & 0.787211 & 2.929231 \\
\hline
\end{tabular}




\begin{tabular}{|c|r|l|}
\hline \multicolumn{3}{|c|}{$\begin{array}{l}\text { Table - 6 GDP per capita } \\
\text { (current US\$) }\end{array}$} \\
\hline Year & \multicolumn{1}{|l|}{ China } & India \\
\hline 2000 & 949.1781 & 455.4438 \\
\hline 2001 & 1041.638 & 464.7269 \\
\hline 2002 & 1135.448 & 485.5537 \\
\hline 2003 & 1273.641 & 564.6188 \\
\hline 2004 & 1490.38 & 649.7104 \\
\hline 2005 & 1731.125 & 740.1159 \\
\hline 2006 & 2069.344 & 830.1632 \\
\hline 2007 & 2651.26 & 1068.679 \\
\hline 2008 & 3413.589 & 1042.084 \\
\hline 2009 & 3749.272 & 1147.239 \\
\hline 2010 & 4447.756 & 1419.113 \\
\hline 2011 & 5441.759 & 1533.666 \\
\hline 2012 & 6188.194 & 1489.235 \\
\hline Average & 2737.122 & 914.6421 \\
\hline SD & 1766.152 & 396.822 \\
\hline
\end{tabular}

\begin{tabular}{|c|r|r|}
\hline \multicolumn{3}{|l|}{ Table - 7 Inflation, consumer } \\
prices (annual \%) \\
\hline Year & \multicolumn{1}{|c|}{ China } & \multicolumn{1}{l|}{ India } \\
\hline 2000 & 0.255305 & 4.009434 \\
\hline 2001 & 0.722903 & 3.684807 \\
\hline 2002 & -0.76595 & 4.3922 \\
\hline 2003 & 1.15591 & 3.805866 \\
\hline 2004 & 3.884183 & 3.767238 \\
\hline 2005 & 1.821648 & 4.246353 \\
\hline 2006 & 1.463189 & 6.145522 \\
\hline 2007 & 4.750297 & 6.369997 \\
\hline 2008 & 5.864384 & 8.351816 \\
\hline 2009 & -0.70295 & 10.87739 \\
\hline 2010 & 3.314546 & 11.9923 \\
\hline 2011 & 5.41083 & 8.857845 \\
\hline 2012 & 2.65244 & 9.312446 \\
\hline Average & 2.294364 & 6.601016 \\
\hline SD & 2.224346 & 2.952564 \\
\hline
\end{tabular}

